\title{
China's Rise in a Changing World
}

Jane Golley and Ligang Song

Whereas the last three decades of the twentieth century witnessed China rising on to the global economic stage, the first three decades of the twenty-first century are almost certain to bring with them the completion of that rise, not only in economic, but also in political and geopolitical terms. China is now the second-largest economy in the world as measured by national accounts and is well on the way to becoming the largest economy in real terms in the not too distant future. The Chinese economy has contributed positively to world economic growth for decades, even during the global financial crisis (GFC) in which strong domestic growth played a pivotal role in ensuring that world economic growth stayed in positive territory. China's integration into the global economy has brought onefifth of the global population into the world trading system, which has increased global market potential and integration to unprecedented levels. The increased scale and depth of international specialisation propelled by an enlarged world market have offered new opportunities to boost world production, trade and consumption, with the potential for increasing the welfare of all the countries involved.

While many of the global and national benefits of China's economic rise are clear for all to see, so too are many of the costs. China's integration into the global economy has forced a worldwide reallocation of economic activities. This has increased various kinds of friction in China's trading and political relations, as well as generating several globally significant externalities, relating to the following: 1) increased competition from China's low-cost production and the accompanying rising share of Chinese-made products provided to the world market; 2) China's role in global economic imbalances; 3) rising commodity prices, including energy and minerals prices, caused largely by China's rapidly increasing demand for resources to fuel its development; and 4) rising greenhouse emissions, resulting from the rapid pace of industrialisation and increasing standards of living in China (Song 2010).

China's rising economic weight in the global economy is not only affecting its economic and political relations with the rest of the world, but is also changing the global and regional economic and political landscapes in fundamental ways. As pointed out by Findlay and O'Rourke (2007:545), 'in the longer run, the gradual rise of India and China to their natural roles as major economic and political superpowers [is] not only the best news for global human welfare in a generation, but promise[s] to raise a variety of geopolitical challenges which as yet remain unpredictable'. Whatever these challenges turn out to be, China faces the critical task of managing its rise in a way that is palatable to both the domestic and the world communities. A necessary counterpart to this task is that of the world community finding ways to accommodate China's rise that ensure the future stability and prosperity 
of the world economy and polity. In this sense, it is probably safe to say that accommodating a rising China is the most important task facing the world community in the first half of the twenty-first century.

The emergence of major trade and financial imbalances between regions has been the key characteristic of the global economy in recent years. In the real economy, the ever-increasing trade imbalance between the United States and China has been the main contributing factor. China has achieved a position of major relevance in terms of the real economy, with global shares of output, trade, emissions and commodity consumption that rank it as a tier-one power. It has, however, a financial system and a framework of exchange arrangements that presently prevent it from achieving equivalent heft in the financial sphere, with the intermediation of real economy imbalances left by default to the financial systems of industrialised countries. To correct this imbalance, China will need to further deepen the reform of its financial system in order to pave the way for liberalising its capital account and achieving the full convertibility of its currency.

It is against this backdrop of imbalances that China and the other major nations must seek to alter the composition of their economic activity and eventually their balance sheets. The intense distress experienced across the globe as the process of financial de-leveraging accelerated in the middle of the GFC and the uneven signs of stabilisation observed since then have not reduced the enormity of the task.

For China, consistent with the goal of rebalancing the economy, the next wave of rapid growth will need to focus on higher value-added manufacturing, a shift towards the domestic market, a shift of the centre of gravity of growth from the coast to the interior, a vast expansion of the service sector, and the dynamism of small and medium, predominantly private, firms (Overholt 2010). Boosting domestic consumption will take time but there are some clear reform options that will play a positive role, including the development of the social welfare system and the urbanisation of the large number of migrant workers. China can also contribute to the task of rebalancing not by exporting less but by importing more. Moving towards a market-based exchange rate regime is part of the structural approach to addressing the imbalance issues.

Given the sheer size of the Chinese economy, in combination with the extent of its global integration, virtually any structural adjustments in China will have global consequences. Consider as an example the question of how China should best manage its vast quantity of US dollar-denominated assets against the background of dollar depreciation. On the one hand, the depreciation of the dollar generates a real adjustment in boosting US exports and slowing its imports, thereby improving its trade account balance. On the other hand, the depreciation of the dollar also generates a financial adjustment through capital gains for the United States set against the losses for the rest of the world (Serven and Nguyen 2010:7). This presents a major financial risk for China given its massive stock of cross-border assets and its ongoing move towards international financial integration. Given such a risk, 
the diversification of China's cross-border assets away from US dollar assets and short-term assets issued by the United States and other countries is appropriate and inevitable. It is part of a pattern of financial globalisation that has generally positive, as well as occasional negative, implications for the international financial system and the global economy. (Truman 2008:178)

On this occasion, however, should China choose to do so, it would precipitate a further fall of the US dollar, thereby putting more pressure on the United States to raise its interest rates, which is hardly ideal for a country still recovering from crisis. The increasing interdependence of these two major economic powers in terms of trade, investment and now finance as well suggests that cooperation is no longer an option, but a necessity; and in many instances, this point extends across the entire globe.

To assist with bilateral and multilateral cooperation, there is a pressing need for structural adjustments in the institutions that govern the international political and economic system. This is because maintaining relatively open and fair, multilateral political, trading and financial systems is the only effective way in which the behaviour of rising powers can be constrained by a rules-based system, while those of incumbent powers become more accommodating and cooperative. In a world in which China is increasingly expected to play a leadership role, this multilateral framework will provide an important institutional basis from which the expansion of international trade can continue to be a positive-sum rather than a zero-sum game. Only then can globally common goals such as macroeconomic stability, financial integration, poverty reduction, climate change and regional and international security be achieved with success (Song 2010).

The chapters contained in this volume delve into the issues touched on above, and many others besides, to reflect upon the wide range of opportunities and challenges that has emerged in the context of a rising China. While some chapters focus on key bilateral relationships (including with the United States and Australia), others offer either comparative perspectives (for example, with Indonesia on migration and with India on sources of economic growth) or Chinese perspectives on global goals (such as constraining climate change and reforming the international economic system). Some chapters focus on particular markets (for example, petroleum), others on key internal problems (urbanisation and ageing) or on certain aspects of China's global integration (such as the outward direct investment of China's manufacturing firms and China's economic activities in Africa). Despite the wide range of topics and approaches, an overriding theme is this: China's rise is occurring not just in a changing world, it is significantly changing that world as well.

Huw McKay gets the ball rolling in Chapter 2 with his assessment of China's economic performance during the past half-decade of global economic turbulence. McKay demonstrates how China's macroeconomic policy stance is driven by efforts to balance public and private economic activity, which is the key to tracking China's economic growth. He uses up-todate real estate and infrastructure activity as proxies for the private and public sectors, respectively, to demonstrate this point, before examining China's policy response to the global crisis and consequent slowdown in the domestic economy. While China's countercyclical policies support the continuation of high rates of economic growth, the challenge lies in finding ways to achieve this goal that, unlike present methods, do not compound long-term structural problems. 
In the wake of the GFC and with the ongoing rise of emerging economies, there is general consensus that the current international economic order - characterised by US leadership, the US dollar as the cornerstone of the international monetary system, and the roles of key international organisations including the World Bank, the International Monetary Fund (IMF) and the World Trade Organisation (WTO) - is in need of reform. There is, however, virtually no consensus on the direction in which this reform should head. Yiping Huang, Weihua Dang and Jiao Wang take this as their starting point in Chapter 3, which addresses this issue from China's perspective. Their analysis begins with the question of revolution or reform, followed by considerations of the roles of the G2, G7 and G20, the need for IMF reforms, and the optimal global reserve system. The authors conclude with their take on what China wants, what it can offer and what its responsibilities are in terms of shaping a harmonious, cooperative and stable new international order.

Since 2008, China has taken a number of initiatives to promote the international role of the renminbi (RMB). In Chapter 4, Yin-Wong Cheung, Guonan Ma and Robert McCauley interpret these initiatives as part of a medium-term strategy to denominate some of China's international claims in RMB as a means of sharing the currency exposure of China's international balance sheet. While acknowledging some of the constraints to RMB internationalisation - including the hotly debated issue of currency undervaluation and misperceptions about the RMB-US dollar link - the chapter is essentially optimistic about the future opportunities for both China and its trading partners to denominate some of their risks in $\mathrm{RMB}$.

In Chapter 5, Kunwang Li and Ligang Song enter the debate regarding whether or not the technological content and quality of China's exports are commensurate with China's current level of development. They contend the views of Dani Rodrik, who, among others, has claimed that China is punching well above its weight in terms of export quality, as evidenced by the rising share of high-technology exports. Li and Song take a closer look at China's role in internationally fragmented production processes to show that this view overstates China's export quality - by attributing the foreign technology already embodied in imports of parts and components as China's own. Their calculations indicate that, to the contrary, China is in fact punching below its weight in terms of technological and quality upgrading. Li and Song call for policy measures to speed up China's climb up the global technological ladder during the next phase of growth and development.

A book on the global implications of China's rise would be incomplete without a chapter on foreign direct investment (FDI), with cumulative inflows of close to US\$1 trillion in the past three decades. In Chapter 6, Chunlai Chen provides an up-to-date assessment of China's changing attitude towards FDI - from restricting to passively attracting and then to actively selecting inward FDI - as reflected in the evolution of its FDI policies, laws and regulations. Despite China's significant progress in conforming to the WTO's investmentrelated principles, Chen calls for further improvements with respect to transparency, national treatment and the protection of intellectual property rights. While Chinese policy makers need to ensure that FDI policies are consistent with their own internal development goals, the provision of equal incentives and opportunities for foreign and domestic firms, combined with stronger enforcement of intellectual property rights, will be essential for sustaining China as a globally competitive destination for FDI in the future. 
In Chapter 7, Bijun Wang and Huiyao Wang turn to the more recent phenomenon of China's outward direct investment (ODI), which has surged since 2004 to make China the world's largest developing economy investor and fifth-largest investor after the United States, France, Japan and Germany. Wang and Wang focus on the ODI of China's manufacturing firms and argue that the modern globalised world in which these firms are operating is substantially different from the world that faced multinational corporations (MNCs) decades ago. As such, their motivations and competitive advantages are also quite different, with the majority of Chinese firms seeking technology, rather than cheap labour, and with the support of a range of preferential policies under the Central Government's 'Going Out' strategy. This (often non-transparent) government support poses the fairly unique problem facing Chinese firms in global markets: that of convincing host-country political parties, lobby groups, competitors, communities and the media that 'ODI with Chinese characteristics' is not something to be feared.

Andrew Kennedy discusses China's 'petroleum predicament' in Chapter 8, highlighting both the challenges and the opportunities facing China (and implicitly, the rest of the world) in its search for energy security. While Chinese leaders are clearly aware of the necessity of dealing with the inevitable rise in China's import dependence on oil, Kennedy argues that the policies adopted so far have not gone far enough, focusing as they have on unilateral efforts to build up domestic capacity and on bilateral agreements with energy-producing states. He calls for stronger multilateral engagement with other prominent oil importers, and in particular with the International Energy Agency. This would not only enhance the prospects for global petroleum security, but would also be an opportune way for all involved to signal a cooperative stance in dealing with China's rise.

Yongsheng Zhang's Chapter 9 addresses one of, if not, the greatest global problems of the twenty-first century: combating global climate change. For Zhang, there are two prerequisites for achieving the long-term goal of controlling global temperature rises at $2^{\circ} \mathrm{C}$ through to 2050: global carbon equity and low-carbon growth. The first calls for industrialised countries to take responsibility for their historical emissions, which remain present in the atmosphere and thereby constrain the emission space available for development in the less developed parts of the world. By incorporating these into country-level per capita emission entitlements, Zhang shows that industrialised countries have run up serious emission deficits, which, if acknowledged, would provide the incentive for a dramatic shift in their modes of growth - towards low-carbon growth. Despite his pessimism when it comes to global climate change negotiations, Zhang is optimistic about the role that China can play in facilitating this shift, which he sees as a great opportunity for the most profound development transformation since the Industrial Revolution.

Geoffrey Garrett and Wing Thye Woo provide us with Chapters 10 and 11, respectively, on the changing nature of Sino-American relations - the most critical bilateral economic relationship on the global stage. Garrett produces an extremely balanced assessment of what the world might expect as the United States enters a period of relative economic decline (visa-vis Asia and as opposed to dramatic collapse), while still maintaining a dominant cultural and political reach. Garrett argues that the massive stakes involved in the relationshipboth the upside of their enormous economic ties and the downside of the damage that armed conflict would incur - should give us confidence that both countries will continue to 
manage their relations effectively in the foreseeable future. He notes that the biggest issues for both countries are in fact domestic, rather than concerning the relationship between the two - a point also made by Woo with specific reference to improving bilateral trade imbalances. Garrett is optimistic that the inevitable frictions as a rising power confronts a waning one will be outweighed by the increasing diplomatic skills of each power in managing these frictions, as seen in their responses to the global financial crisis. Likewise, Woo is hopeful that enlightened self-interest will guide the United States and China to be earnest in defusing their bilateral trade tensions.

The Australia-China economic relationship is examined in Chapter 12 by Christopher Findlay. Findlay provides a wide range of evidence to show that this relationship has moved from strength to strength, with China not only being Australia's number-one trading partner, but also now the largest source of foreign students and tourists (two key service export sectors), as well as an increasingly important source of investment in the resource sector, which has underpinned Australian prosperity in recent decades. Findlay makes it clear, however, that this strengthening economic relationship is not without challenges, of which he identifies three sets: the 'now' challenge, the 'end of the boom' challenge and the challenge of grasping new opportunities. His conclusions point to a broad set of policy and institutional reforms that will be required for Australia to continue to benefit from its relationship with China in the future, relating to resource taxation, migration, visas and airline services, labour productivity and flexibility, and ongoing reductions in barriers to trade.

Apart from the consensus that Chinese aid in Africa has increased rapidly in recent years, there is little agreement on the details of this contentious issue. Deborah Brautigam contributes to the ongoing debate in Chapter 13, which provides clear insight into what constitutes Chinese 'development aid' in Africa, where it is going and in what quantities, the motivations behind it, and its impact on African economic development. In so doing, she makes the critical point that only a small proportion of the variety of instruments used by the Chinese for official finance in Africa can be categorised as official development aid (ODA). Grasping the realities of Chinese development aid and economic cooperation (much of which is not aid) in Africa is an essential prerequisite for understanding the many issues surrounding China's engagement in Africa-for the African countries themselves, for Africa's traditional partners, and for China itself.

Peter Robertson takes on the world's present and future 'titans' in his comparative analysis of Chinese and Indian economic growth in Chapter 14. Robertson draws on the neoclassical growth model to argue that, contrary to widely held beliefs, China's remarkable growth performance during the past three decades might have far more to do with the growth in its human-capital stock than with the growth in its physical-capital stock. His estimates show that the growth of human-capital stock has accounted for a significant proportion of economic growth in both countries to date, but particularly in China, where significant achievements have been made in increasing the proportion of the workforce with secondary or higher levels of educational attainment. The key challenge for both countries lies in ensuring that their vast populations - in urban and rural areas alike - are provided with equal opportunities to equip themselves with the education and skills that will be a key source of growth for the two titans in the decades ahead. 
In Chapter 15, Paul Frijters, Xin Meng and Budy Resosudarmo provide a comparative analysis of China and Indonesia - two of the world's most populous countries in which millions of migrants have made significant contributions to economic development. In particular, they examine how different institutional settings in China and Indonesia affect the wage outcomes of rural-to-urban migrants. Although both countries are rapidly urbanising, Chinese cities place heavy restrictions on migrants' access to high-wage occupations, while Indonesian cities are far more laissez faire. Their analysis shows that Chinese migrants earn significantly less than their urban residential counterparts, while Indonesian migrants earn slightly more. This difference highlights the need for Chinese policy makers to reform the 'two-class residency system' in Chinese cities - an increasingly urgent issue in light of the unstoppable process of urbanisation and the purported commitment to reducing income inequality.

China's dramatic economic rise during the past three decades has been accompanied by - and indeed, to some extent caused by - the most rapid 'demographic transition' experienced at any time anywhere in world history. In Chapter 16, Zhongwei Zhao examines this transition from a global perspective, identifying some of the key challenges China is facing as it enters the unique situation of getting old before it gets rich. Arguing that a relaxation of the one-child policy is unlikely to impact significantly on future fertility rates, Zhao calls for careful consideration of the long-term impact of below-replacement fertility and the appropriate policy response. A basic prerequisite for preparing for the upcoming challenges is an improvement in demographic data collection and quality, without which it will be impossible to know what lies ahead for Chinese demographic change, and its economic consequences.

In Chapter 17, Yang Du and Meiyan Wang look more closely at one of China's key demographic challenges - that of population ageing, and what it might mean for patterns of household consumption in the future. Du and Wang show that the determination of consumption choices over the life cycle is complicated in China's case by its status as a developing and transitional economy, with insufficient resources for elderly support, a pension system still under construction, and incomplete health and education system reforms. They draw on a recent urban household survey to examine the relationship between ageing and household consumption - an understanding of which is particularly important in the context of the Chinese leadership's goal of increasing the role of domestic demand in China's economic growth. Their findings suggest that the weak state of the healthcare system might be the biggest constraint to raising consumption in China's ageing society.

Finally, in Chapter 18, Xiaolu Wang examines the urban development strategy in China from an international perspective. He takes up the ongoing debate as to whether the Government's urbanisation strategy should focus on the development of small and medium-size cities and towns, or whether, instead, China should allow and encourage the emergence of 'mega-cities'. His econometric analysis using cross-country data shows that the percentage of China's population living in mega-cities is far below international common practice, with the implication that an additional 273 million people should transfer to megacities in the coming two decades. As with so many issues surrounding China's development process, the sheer size of its population presents the greatest challenge of all. 


\section{Bibliography}

Cooper, N. R. 2008, 'Global imbalances: globalisation, demography and sustainability', Journal of Economic Perspectives, vol. 22, no. 3, pp. 93-112.

Findlay, R. and O'Rourke, K. H. 2007, Power and Plenty: Trade, war, and the world economy in the second millennium, Princeton University Press, Princeton, NJ, and Oxford, UK.

McKay, H. and Song, L. 2010, 'China as a global manufacturing powerhouse: strategic considerations and structural adjustment', China \& World Economy, vol. 18, no. 1 (February), pp. 1-32.

Overholt, W. H. 2010, 'China in the financial crisis: rising influence, rising challenges', The Washington Quarterly, vol. 33, no. 1, pp. 21-34.

Serven, L. and Nguyen, H. 2010, Global imbalances before and after the global crisis, Policy Research Paper 5354, The World Bank, Washington, DC.

Song, L. 2010, China's rapid growth and development: an historical and international context, Presented at the Thirty-Fourth PAFTAD Conference on China's Role in the World Economy, 7-9 December 2010, Peking University, Beijing.

Truman, E. M. 2008, 'The management of China's international reserves: China and a sovereign fund scoreboard', in M. Goldstein and N. R. Lardy (eds), Debating China's Exchange Rate Policy, Peterson Institute for International Economics, Washington, DC, pp. 169-93. 